\title{
The Fluorescence Characteristic of AO-RB-SDS-GMFX and the Determination of Gemifloxacin
}

\author{
Huiping Xi \\ School of Resource and Environmental Engineering \\ Wuhan University of Technology, Wuhan, China \\ He'nan Quality Polytechnic, Pingdingshan, henan, China \\ Xihuiping1@163.com
}

\author{
Xiuwei Fang \\ He'nan Quality Polytechnic \\ Pingdingshan, henan, China \\ fangxiuwei@sohu.com
}

\begin{abstract}
A new method for the determination of Gemifloxacin (GMFX) indirectly was developed by using energy transfer of Acridine Orange (AO) - Rhodamine B (RB) fluorescence resonance. It was found that in the $\mathbf{p H}=7.00$ Britton-Robinson (B-R) buffer solution and sodium dodecyl sulfate (SDS) medium, effective energy transfer could occur between $A O$ and $R B$, the fluorescence of $R B$ was enhanced. The fluorescence intensity of $\mathrm{RB}$ quenched with the addition of the GMFX. Using this method to determine the GMFX tablet, the results were consistent with high performance liquid chromatography (HPLC) method, the sample recovery was 98.58 102.16\%, the relative standard deviation (RSD) was $0.68 \sim 2.2 \%$, the detection limit of this method was $0.025 \mathrm{mg} \cdot$ $\mathbf{L}^{-1}$. Experiments showed that this method was simple, rapid, accurate, and sensitive.
\end{abstract}

Keywords-Gemifloxacin; fluorescence resonance energy transfer; fluorescence quenching; Acridine Orange; Rhodamine B

\section{INTRODUCTION}

Gemifloxacin (GMFX) is the fourth-generation fluoroquinolone antibacterial drug developed by the LG company of South Korea and the GSK company of British in April 2003, approved by the Food and Drug Administration (FDA) on sale in America and approved by the State Food and Drug Administration (SFDA) in China in July 2006. GMFX is a rapid broad-spectrum fungicide, especially enhanced its resistance of the $\mathrm{G}^{+}$bacteria. It shows strong antibacterial activity of Streptococcus pneumoniae, and its antibacterial activity is not affected by sensitivity and drug resistance of beta lactam and large ring lactone class antibiotic. GMFX has good curative effect in methicillin-resistant staphylococcus aureus and respiratory pathogens such as haemophilus influenzae, mucositis mora bacteria and pneumococcal. However, as far as we know, there are few reports on determination methods of GMFX, such as high performance liquid chromatography [1-2], capillary electrophoresis method [3], LC - MS/MS method [4], fluorescence quenching method [5]. But the research of determination the effect of GMFX using fluorescence resonance energy transfer quenching method has not yet been reported.

Fluorescence resonance energy transfer refers to the electronic excitation energy to pass between the proper energy and donor receptor, and its transmission distance can be up to $10.0 \mathrm{~nm}$ [6]. In recent years fluorescence energy transfer

Technology between the dye molecules has been widely used in studying the structure, property, function of biological macromolecular [7]. This method has characteristics of high sensitivity compared with spectrophotometry, small light interference by Rayleigh scattering features and good reproducibility compared with conventional fluorescent method and resonance light scattering [8]. In this paper, the energy transfer system of $\mathrm{AO}$ as energy donor, $\mathrm{RB}$ as energy receptor in sodium dodecyl sulfate (SDS) medium was studied. It was found that when the molar ratio of $\mathrm{AO}$ and $\mathrm{RB}$ was $1.5: 1$, the energy transfer effect was best, and the addition of Gemifloxacin could make the fluorescence of RB quenching. This paper reports a new method for the determination of GMFX by using energy transfer fluorescence quenching of AO-RB.

\section{EXPERIMENTAL}

\section{A. Apparatus and Reagents}

A 970CRT fluorescence spectrophotometer (Shanghai, China) was used for recording fluorescence spectra and making fluorescence measurements. The absorption spectra were made on a Lab-Tech-1000 UV-visible spectrophotometer (Beijing, China). The $\mathrm{pH}$ was measured with a Model pHs-3CT meter (Shanghai, China).

Gemifloxacin reference substance (Gemifioxacin mesylate) was purchased from Shanghai institute of organic chemistry (purity $\geq 99 \%$ ). Gemifloxacin mesylate tablets were purchased from Korea LG life sciences Ltd (specifications: $0.32 \mathrm{~g}$ per piece, approval number: H20060223).

The stock solution of Gemifloxacin: $50 \mathrm{mg}$ Gemifloxacin reference substance was weighed accurately and dissolved in appropriate amount of water to make 1.00 $\mathrm{mg} \cdot \mathrm{ml}^{-1}$ stock solution.

Reference substance solution: the stock solution was drawn $1.00 \mathrm{ml}$ then diluted to $0.01 \mathrm{mg} \cdot \mathrm{ml}^{-1}$ with doubly distilled water as Reference substance solutions.

B-R buffer solution: B-R buffer solution were prepared by taking the mixed solution of boric acid, phosphoric acid and acetic acid (the concentration of $0.04 \mathrm{~mol} \cdot \mathrm{L}^{-1}$ ) and $0.20 \mathrm{~mol} \cdot \mathrm{L}^{-1} \mathrm{NaOH}$ was added to adjust to the desired $\mathrm{pH}$ value.

Acridine Orange solution: $3.0 \times 10^{-6} \mathrm{~mol} \cdot \mathrm{L}^{-1}$. 
Rhodamine B solution: $2.0 \times 10^{-6} \mathrm{~mol} \cdot \mathrm{L}^{-1}$.

Sodium dodecyl sulfate solution: $1.0 \times 10^{-2} \mathrm{~mol} \cdot \mathrm{L}^{-1}$.

All reagents were of analytical reagent grade without further purification. Water used throughout was doubly distilled water.

\section{B. Experimental Methods}

$1 \mathrm{ml} \mathrm{B-R} \mathrm{buffer} \mathrm{solution(pH=7.00),} 1 \mathrm{ml}$ AO solution, 1 $\mathrm{ml} \mathrm{RB}$ solution, $0.50 \mathrm{ml}$ SDS solution were transferred into the $10 \mathrm{ml}$ volumetric flask in turn, and an appropriate quantity of working solution or sample solution of was added. The mixture was diluted to $10 \mathrm{ml}$ with water and thoroughly mixed. Then the fluorescence intensities of the sample (F) and the blank (F0) solutions were measured with the following settings of the spectrofluorimeter: excitation wavelength, $\lambda \mathrm{ex}=470 \mathrm{~nm}$, emission wavelength, $\lambda \mathrm{em}=$ $576 \mathrm{~nm}$, excitation and emission band-passes, $10 \mathrm{~nm}$.

\section{RESULTS AND DISCUSSION}

\section{A. Spectral Characteristics}

The excitation wavelengths and the emission wavelength of Strong fluorescent dye AO were $\lambda$ ex $=495 \mathrm{~nm}$, $\lambda$ em $=530 \mathrm{~nm}$ respectively, and the absorption peak of $\mathrm{RB}$ monomer $(\lambda$ Max $=556 \mathrm{~nm})$ was far from the fluorescence peak of $\mathrm{AO}$, it was difficulty to transfer energy efficiently (curve 5 in Fig. 1). When the anionic surface active agent, SDS solution was added in RB, cationic dye formed two polymers under the action of the right amount of SDS and the maximum absorption peak of the polymer was at 529 nm (Fig. 2). It was indicated that efficient energy transfer could occur between $\mathrm{RB}$ and $\mathrm{AO}$, the fluorescent peak of donor in mixing system (AO) had dropped significantly whereas the receptor (RB) fluorescence peak had a significant increase (curve 6 in Fig. 1). When the dosage of SDS is $0.50 \mathrm{ml}, \lambda$ ex $=470 \mathrm{~nm}, \lambda$ em $=576 \mathrm{~nm}$, the effect of energy transfer was best.

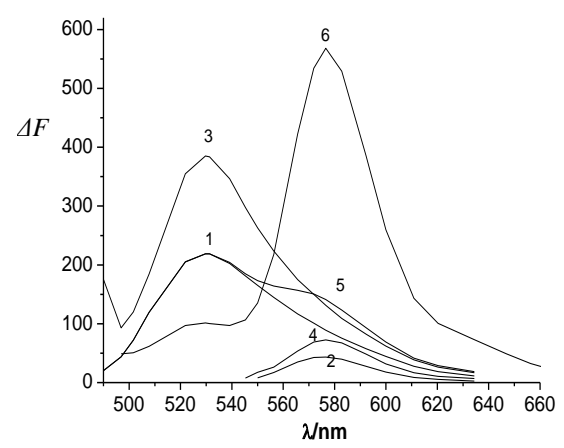

Figure 1. Fluorescence spectra $1 \mathrm{AO}+\mathrm{B}-\mathrm{R}, 2 \mathrm{RB}+\mathrm{B}-\mathrm{R}, 3 \mathrm{AO}+\mathrm{B}-\mathrm{R}+\mathrm{SDS}$ $4 \mathrm{RB}+\mathrm{B}-\mathrm{R}+\mathrm{SDS}, 5 \mathrm{AO}+\mathrm{RB}+\mathrm{B}-\mathrm{R}, 6 \mathrm{AO}+\mathrm{RB}+\mathrm{B}-\mathrm{R}+\mathrm{SDS}$

\section{B. The Influence of Energy Donor and Acceptor Dosage on $A O-R B-S D S$ System}

According to the experimental method, fixed the other experimental conditions, the molar ratio of $\mathrm{AO}$ and $\mathrm{RB}$ was changed and the fluorescence spectrum of system was drawn. The results showed that: when the molar ratio of AO and $\mathrm{RB}$ was $1.5: 1$, the energy transfer effect between $\mathrm{AO}$ and $\mathrm{RB}$ was best. In this experiment, the dosage of $3 \times 10^{-6}$ $\mathrm{mol} \cdot \mathrm{L}^{-1} \mathrm{AO}$ was $1 \mathrm{ml}$, the $2 \times 10^{-6} \mathrm{~mol} \cdot \mathrm{L}^{-1} \mathrm{RB}$ was 1.00 $\mathrm{ml}$.

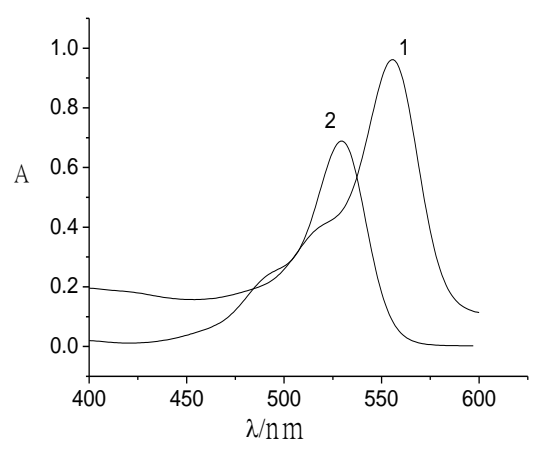

Figure 2. Absorption spectra of RB and RB-SDS system 1 RB, 2 RB-SDS

\section{The Influence of GMFX on AO-RB-SDS System}

The effect of GMFX on the AO-RB-SDS system was investigated by changing the concentration of GMFX. The fluorescence intensity $\triangle \mathrm{F}$ of GMFX system with different concentration was determined at $470 \mathrm{~nm}$ as the excitation wavelength, in the range of $500 \sim 600 \mathrm{~nm}$. From Fig. 3, it could be seen that with the increase in the concentration of GMFX, the $\Delta \mathrm{F}$ value of AO-RB-SDS system decreased.

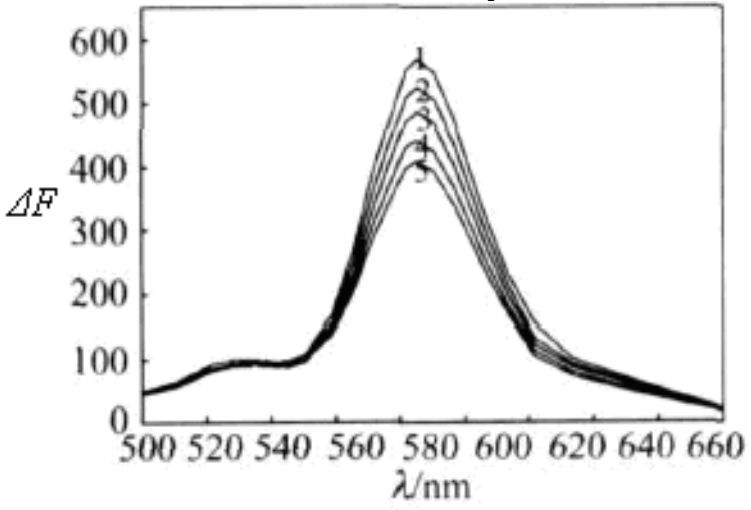

Figure 3. Fig.3 Effect of GMFX on the Fluorescence of AO-RB-SDS

1. $\mathrm{AO}+\mathrm{RB}+\mathrm{B}-\mathrm{R}+\mathrm{SDS}$

2. $\mathrm{AO}+\mathrm{RB}+\mathrm{B}-\mathrm{R}+\mathrm{SDS}+0.05 \mu \mathrm{g} \cdot \mathrm{ml}-1 \mathrm{GMFX}$

3. $\mathrm{AO}+\mathrm{RB}+\mathrm{B}-\mathrm{R}+\mathrm{SDS}+0.10 \mu \mathrm{g} \cdot \mathrm{ml}-1 \mathrm{GMFX}$

4. $\mathrm{AO}+\mathrm{RB}+\mathrm{B}-\mathrm{R}+\mathrm{SDS}+0.15 \mu \mathrm{g} \cdot \mathrm{ml}-1 \mathrm{GMFX}$

5. $\mathrm{AO}+\mathrm{RB}+\mathrm{B}-\mathrm{R}+\mathrm{SDS}+0.20 \mu \mathrm{g} \cdot \mathrm{ml}-1 \mathrm{GMFX}$

D. The study of Fluorescence Properties of AO-RB-SDSGMFX System

1) Effect of $p H$ :The fluorescence enhancement of the system was greatly dependent on the $\mathrm{pH}$ value since the $\mathrm{pH}$ value had an effect on the nature of the AO and RB. The effect of $\mathrm{pH}$ on the fluorescence intensity of the system was 
studied in B-R buffer solution with different $\mathrm{pH}$ values. The experiments indicated that the difference of fluorescence intensity in the absence and presence of GMFX reached maximum and kept almost unchanged when B-R buffer solution of $\mathrm{pH}=7.00$ was used. In this work, we chose the $\mathrm{pH}$ 7.0 B-R solution as the buffer system.

2) Effect of the dosage of the buffer solution:The concentration of the buffer solution was also studied. The results showed that When the amount of B-R buffer solution was in the range $0.00 \sim 1.00 \mathrm{ml}$, the $\Delta \mathrm{F}$ value of the system increased with the amount of buffer solution increase, when the amount of B-R buffer solution is greater than $1.00 \mathrm{ml}$, $\Delta \mathrm{F}$ value of the system was stable basically, In this experiment, $1.00 \mathrm{ml}$ PH 7.00 B-R buffer solution was used.

3) Effect of the dosage of SDS:The experiments showed that when the amount of SDS solution was $0.50 \mathrm{ml}$, the $\Delta \mathrm{F}$ value of the system reached maximum. So SDS solution used in this experiment was $0.50 \mathrm{ml}$.

4) Effect of reaction time:The reaction time was also studied. The results showed that when the reaction time was within $1 \mathrm{~h}$, the $\Delta \mathrm{F}$ value of system was very stable. In this work, the reaction time was $10 \mathrm{~min}$.

\section{E. Interference Experiment}

According to the experimental method, $1 \mathrm{ml} \mathrm{pH=7.00}$ B-R buffer solution was added in five $10 \mathrm{ml}$ volumetric flasks, and then $1 \mathrm{ml}$ acridine orange solution, $1 \mathrm{ml} \mathrm{RB}$ solution for, $0.50 \mathrm{ml}$ SDS solution, $2 \mathrm{ml}$ GMFX solution were added in turn. One of which was as a contrast and glucose, dextrin, $\mathrm{NaCl}$, soluble starch were added in the other four volumetric flasks respectively as compared. The experiment showed that 500 times the glucose, dextrin, $\mathrm{NaCl}$, soluble starch had no obvious influence on the experiment in the error range of $\pm 5 \%$.

\section{F. Standard Curves and the Detection Limit}

According to the experimental method, $1 \mathrm{ml} \mathrm{B-R}$ buffer solution, $1 \mathrm{ml}$ AO solution, $1 \mathrm{ml} \mathrm{RB}$ solution, $0.50 \mathrm{Ml}$ SDS solution and the amount of GMFX reference substance solution were added in $10 \mathrm{ml}$ volumetric flask, diluted with water and mixed. The working curves were drawn with mass concentration as the abscissa, fluorescence intensity as the ordinate. The results showed that mass concentration of GMFX had a good linear relationship with the fluorescence intensity in the range of $0.05 \sim 0.50 \mathrm{mg} \cdot \mathrm{L}^{-1}$, the linear regression equation is: $\mathrm{Y}=18.65+509.8 \mathrm{C}(\mathrm{r}=0.9989)$, the detection limit was $0.025 \mathrm{mg} \cdot \mathrm{L}^{-1}$.

\section{G. Determination of GMFX in Tablets}

The mesylate GMFX sample was dissolved in the water to appropriate concentration, filtered drily, the primary filtrate was discarded and then the continued filtrate was collected as sample solution. The sample solution was measured on the best experimental conditions with the working curve method, and the results were compared with HPLC method. The measurement results were shown in Table 1.

TABLE I. THE MEASUREMENT RESULTS OF GMFX IN TABLETS (EQUIVALENT TO THE LABELED AMOUNT \%)

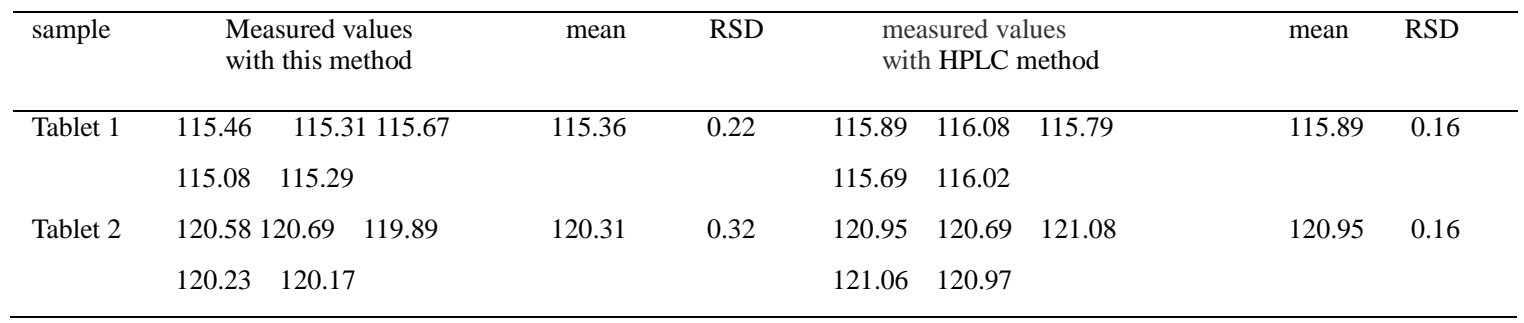

TABLE II. RECOVERY TEST $(\mathrm{N}=5)$

\begin{tabular}{|c|c|c|c|c|c|c|c|c|c|}
\hline added amount(mg) & & & $\begin{array}{l}\text { heasured } \\
\qquad(\mathrm{mg})\end{array}$ & values & & & $\begin{array}{l}\text { Recovery } \\
(\%)\end{array}$ & $\begin{array}{c}\text { mean recovery } \\
(\%)\end{array}$ & $\begin{array}{l}\mathrm{RSD} \\
(\%)\end{array}$ \\
\hline 100 & 103.14 & 103.14 & 98.24 & 103.14 & 103.14 & 103.14103 .14 & $\begin{array}{lll}98.24 & 103.14 & 103.14\end{array}$ & 102.16 & 2.2 \\
\hline 150 & 151.47 & 150.34 & 150.02 & 149.69 & 148.62 & 100.98100 .23 & $100.01 \quad 99.79$ & 100.02 & 0.68 \\
\hline 200 & 198.47 & 198.47 & 193.88 & 196.47 & 198.47 & $99.24 \quad 99.24$ & $96.94 \quad 98.24 \quad 99.24$ & 98.58 & 1.0 \\
\hline
\end{tabular}

\section{H. Recovery Test}

The appropriate amount of GMFX reference solution was added in the sample solution, and the recovery was determined (Table 2).

\section{CONCLUSIONS}

A new method was proposed for the determination of Gemifloxacin (GMFX) indirectly by using energy transfer of AO-RB fluorescence resonance. In addition to its stability, reproducibility and rapidity, this method had a wide linear range and low detection limit.

\section{REFERENCES}

[1] Sharif S, Khan I U, Sheikh T A, et al. Acta Chromatographica, 2011, 23(1):95

[2] Nagavali D, Abirami G, Karar S K. Journal of Pharmary Research, 
2011, 4(6):1701

[3] Elbashir A A, Saad B, Ali A S M, et al. Journal of Liquid Chromatography, 2008, 31:1465

[4] Nageswara Raoa R, Gangu Naidua Ch, Guru Prasada $\mathrm{K}$, et al. Biomedical Chromatography, 2011，25:1222

[5] ZHONG Wen-ying, WANG Yan, HUANG Bin, et al. China Academic Journal Electronic Publishing House, 2012, 32(6):1570
[6] CHEN Guo-zhen, HUANG Xian-zhi, ZHENG Zhu-zhi, et al. Fluorescence Analysis [M], Beijing:Science Press, 1990:122

[7] LI Xiao-Yan, LI Shu-wei, ZENG Ming, et al. Chinese Journal of Analysis Laboratory, 2006, 25(4):38

[8] FU Li, LIU Bao-sheng, CAO Dong-Lin, et al. Metallurgical Analysis, 2007, $27(7): 26$ 